\title{
TYÖSUOJELUINTERVENTIO TURUN TELAKALLA ${ }^{1}$
}

Työskentely laivanrakennusteollisuudessa osana metalliteollisuutta on tilastollisesti tarkastellen yksi vaarallisimmista tavoista tienata leipänsä. Suomen suurin laivanrakennusteollisuuden työnantaja Kvaerner MasaYards (nykyinen Aker Finnyards) aloitti vuonna 2000 uudenlaisen panostuksen työsuojeluun. Mitä hyötyä interventiosta oli ja mitä lopulta jäi käteen?

\section{PETRI HALLIKAINEN}

$\mathrm{T}$ yösuojeluinterventio TEKO (lyhenne sanoista "tekemällä oppii”) käynnistettiin Turun telakalla vuonna 2000. Hankkeen päätarkoituksena oli (1) noudattaa Euroopan Unionin työsuojeludirektiiviä 89/391², (2) lisätä yrityksen kilpailukykyä ja (3) pienentää työn kannalta olennaisia riskejä sekä vähentää työpaikkaonnettomuuksia ja sairauspoissaoloja kehittämällä telakan työturvallisuuskulttuuria. (Ks. esim. Cox \& Cox 1996; Ruuhilehto \& Vilppola 2000.) Kehittämiseen pyrittiin systemaattisella työssäoppimisella. Lähtökohta oli, etteivät työsuojeluongelmat ole ainoastaan ympäristön ja teknisten tekijöiden, vaan myös työssä opittujen asenteiden sekä työtapojen ja -rutiinien tuotoksia. Näin ollen esimerkiksi riskikäyttäytymiseen, kuten haluttomuuteen käyttää relevantteja suojavälineitä, kyettäisiin parhaiten vaikuttamaan myönteisesti jatkuvan tekemällä oppimisen avulla. (Rinne \& Hallikainen 2004; Hallikainen 2004.)

\section{INTERVENTIO TOTEUTUSTAPA}

Interventio piti sisällään useita osa-alueita, josta tärkeimmät olivat työpaikkaohjaajien koulutus ja työpaikkaohjaus, työtapaohjeiden tekeminen ja soveltaminen työssä, turvallisuuspalaverit sekä työympäristön ja -välineiden kehittäminen osastoilla. Keskityn tässä lähinnä ohjaajien koulutukseen ja työtapaohjeiden tekemiseen.

Koulutusjakso sisälsi seuraavia projektin kannalta keskeisiä seikkoja:

- oman työn pohdinta työturvallisuuden näkökulmasta (esimerkiksi kuinka opastaa työntekijöitä siten, että he ottavat huomioon turvallisuusnäkökohdat)
- työasentoja koskeva opastus (esim. kuinka suorittaa työtehtävä siten, että fyysinen kuormitus on mahdollisimman pieni)

- tietoa työturvallisuudesta (esim. mitä vaaroja ja haittoja erilaisiin työtehtäviin liittyy)

Työtapaohjeiden tekemisen tarkoitus puolestaan oli laatia esitys työprosessista tai työvälineen käytöstä, erityisesti kurssilla opittuja tur-

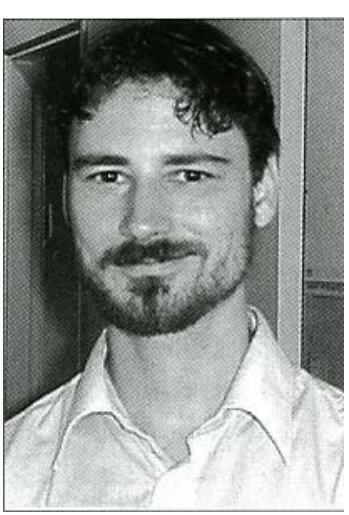

Petri Hallikainen vallisuustekijöitä painottaen. Valmiin ohjeen tarkoituksena on antaa käyttäjälleen kokonaisvaltainen ja ajankohtainen (ohjeita voidaan päivittää tarvittaessa) kuva työprosessin kulusta. Tapauskohtaisesti ohjeita tekivät joko yksittäiset tiimit tai työpaikkaohjaajat. Ohjeiden valmistus alkoi eri osastoilla ainakin kahdesta lähtökohdasta: saatettiin esimerkiksi pohtia, mitkä työtehtävät vaatisivat erityistä huomiota, toisaalta saatettiin keskittyä vaarallisiin prosesseihin ja mallintaa turvallisempi työtapa.

Telakan työturvallisuustilanteen seurantaan käytettiin lukuisia ei-toivottujen tapahtumien seurantaan suunniteltuja mittareita ja tilastoja. (Ks. Koskensyrjä \& Vainio 1990, 40.) Näitä olivat mm. tapaturmataajuus (tapaturmia miljoonaa työtuntia kohti), lähestapaturmat ja palonalkujen määrä laivassa.

TEKO:n vaikutusten seuraamista varten toteutettiin yhteensä viisi kyselyä. Kaksi näistä liittyi työpaikkaohjaajille annetun koulutuksen arvioin- 
tiin. Niiden tarkoituksena oli selvittää työntekijöiden käsityksiä koulutuksesta. Arviointikyselyihin osallistui yhteensä 30 kurssilaista.

Kolme muuta kyselyä toteutettiin siten, että ne pyrkivät selvittämään yksittäisiä työturvallisuuteen ja telakan oloihin liittyviä ongelmia. Kyselyssä 1 (marraskuussa 2000, vastaajina työpaikkaohjaajat, $\mathrm{N}=45$ ) kysymysten painopisteenä oli terveys ja turvallisuus, kyselyssä 2 (helmikuussa 2001, vastaajina työpaikkaohjaajat, N=39) kartoitettiin erityisesti TEKO:n vaikutuksia. Kysely 3 (tammikuussa 2002, vastaajina työpaikkaohjaajat, työnjohtajat ja insinöörit, $\mathrm{N}=119$ ) kysymyksissä painottuivat niin ikään TEKO:n vaikutukset. Tällöin vastaajakunta oli kuitenkin laajempi ja projekti oli edennyt pitemmälle. Viimeisen kyselyn etu oli myös siinä, että sitä suunniteltaessa oli mahdollista hyödyntää teemahaastatteluista saatuja tietoja. Vastaajat täyttivät lomakkeensa työajallaan. Kaikki vastaajat olivat miehiä.

Tutkimusta varten haastateltiin noin puolet ( $N=26)$ niistä n. 50:stä työntekijästä, jotka osallistuivat TEKO -hankkeeseen vuosina 2000-2002 joko työpaikkaohjaajan tai työnjohtajan roolissa. Heidän lisäkseen haastatteluihin osallistui joitain sellaisia työntekijöitä, jotka eivät olleet mukana koulutuksessa, mutta tunsivat projektin hyvin $(n=3)$. Haastateltavat edustivat yleisimpiä telakan metallityömiehiä, kuten levyseppiä, hitsaajia ja asentajia.

\section{KOULUTETTIIN TYÖPAIKKAOHJAAJIA}

Työpaikkaohjaajan koulutukseen valitut olivat kokeneita telakan työntekijöitä (työvuosia telakalla keskimäärin 25). Valintaprosessit vaihtelivat osastoittain: joillain osastoilla työntekijät valitsivat - esimerkiksi äänestämällä - omat koulutettavansa, toisilla osastoilla aloite tuli työnjohdolta. Koulutukseen lähteminen oli vapaaehtoista.

Yleisesti ottaen työpaikkaohjaajiksi koulutettavien suhtautuminen kurssiin oli joko myönteistä tai neutraalia. Esimerkiksi 24 vastaajaa 30:sta arviointikyselyyn vastanneesta oli sitä mieltä, että kurssin pituus oli sopiva. Ainoastaan kolmen vastaajan mielestä kurssi oli liian pitkä ja yhden mielestä liian lyhyt. Sopivan mittaiseksi kurssia arvioineet kehuivat lomakkeen avoimissa kohdissa mm. kurssin tiiviyttä ja sopivaa kestoa asiamäärään nähden. Liian pitkäkestoiseksi kurssia moittineet kommentoivat erityisesti tiettyjen it- sestään selvänä pitämiensä asioiden liiallista toistoa: monet työturvallisuusteemat oli tuttuja jo ammattikoulutuksesta ja kursseista.

Vastaajat olivat niin ikään tyytyväisiä kurssin sisältöön ja teemoihin. Noin seitsemän vastaajaa kymmenestä (67 \%) oli sitä mieltä, että koulutuksesta oli heille hyötyä, kun taas vain yksi kymmenestä (13 \%) koki sen itselleen hyödyttömänä. Tosin kyselystä ilmeni, etteivät kurssin teemat osuneet aivan yksin osallistujien preferenssien kanssa: noin puolet vastaajista oli sitä mieltä, että jotain teemaa oli käsitelty liian vähän. Kohtuullisen harvat (20\%) sen sijaan kokivat, että joitain asioita olisi käsitelty liikaa.

Teemat, joita olisi haluttu käsiteltävän pidempään, koskivat pääasiassa työn sosiaalista ja teknistä organisointia; esitettiin mm. että esimiesten ja alaisten välisestä suhteesta olisi kurssilla voitu keskustella enemmänkin. Lisäksi toivottiin alustavia pedagogisia valmiuksia opastustehtäviä silmällä pitäen. Varsinaista työturvallisuustietoutta, kuten ergonomiaa ja palotuvallisuutta, toivottiin niin ikään enemmän ja esitettiin toivomuksia lisäkoulutuksesta.

Avointen kommenttien mukaan kurssista oli kolmenlaista hyötyä. Ensinnäkin se laajensi kurssilaisten perspektiiviä sekä omalla että muilla osastoilla tehtävään työhön. Toiseksi sen koettiin parantavan keskusteluyhteyksiä eri toimijoiden välillä. Kolmanneksi sen koettiin parantavan työmotivaatiota. Monet vastanneista olivat myös sitä mieltä, että kurssin varsinaiset hyödyt tulisivat esille vasta, kun he olisivat päässeet telakalle varsinaisiin opastustehtäviin.

Vaikka kurssi ylipäätään koettiinkin hyväksi, kurssilaiset pitivät epäkohtana sitä, ettei työnjohtajien, osastoinsinöörien ja työpaikkaohjaajien välille syntynyt aitoa keskustelua työpaikan kehittymisestä. Osittain tämä johtui siitä, että ensiksi mainittujen osallistumien kursseille oli vähäistä. Osan keskustelemattomuudesta selittänee se, että luentopainotteinen opetus ei itsessään aktivoi keskustelemaan. Kuitenkin sikäli kun keskustelua esiintyi, siihen oltiin tyytyväisiä. Huolestuttavaa oli kuitenkin se, että työnantajatahon kiinnittyminen TEKO:n tavoitteisiin ja toteutukseen koettiin heikkona:

"Ja siin olis voinu olla enemmän semmosen vuorovaikutuksen ja semmosen keskustelun maku. Ja sama juttu tota noi näitten, mitä siel oli, meijän kehityspäällikkö ja muut mukana, ni sama juttu: niilt olis kans odottanu jotai 
semmost aktiivisempaa niinku tämmöst otet ... Tämmöst näi niinku vuorovaikutusta näin. Kiinnostusta asiaa yleensäki. “(YH0502).

\section{TYÖTAPAOHJEET \\ TYÖNTEKIJÖIDEN TOIMESTA}

Keskeinen ja kenties näkyvin asia TEKO-interventiossa oli työtapaohjeiden valmistaminen. Erona aikaisempiin, esimerkiksi laite-/prosessisuunnittelijoiden työohjeisiin oli se, että työtapaohjeet syntyivät niiden työntekijöiden toimesta, jotka varsinaisesti itse tekivät kuvattuja töitä. Työtapaohjeiden tekemiseen osallistuivat työntekijät, työpaikkaohjaajat, terveydenhuollon opettajat ja telakan turvallisuushenkilöstö. Kahden viimeksi mainitun panos ohjeisiin oli erityisesti tarkistaa ohjeiden turvallisuus. Erityisen mielenkiintoinen työtapaohjeisiin liittyvä kysymys on, kokivatko työntekijät työtapaohjeet hyvinä opastuksen välineinä ja olivatko ohjeet hyödyllisiä myös kokeneille työntekijöille.

Kyselyn 3 mukaan työtapaohjeet koettiin hyödyllisiksi sekä uusille että kokeneille työntekijöille. Lähes kaikki vastaajat (93\%, N=119) olivat sitä mieltä, että työtapaohje oli hyvä apuväline uusia työntekijöitä opastettaessa. Yleistä (74 \%) oli myös käsitys ohjeiden hyödyllisyydestä kokeneille työntekijöille.

Haastatteluiden mukaan ohje koettiin hyödylliseksi kolmessa mielessä. Ensinnäkin sitä voidaan käyttää tiedonvälityskanavana, jolloin uudelle työntekijälle muodostuu aikaisempaa selkeämpi käsitys telakalla käytettävistä työvälineistä ja niiden käytöstä. Lisäksi sen katsottiin toimivan herätteenä uusien työvälineiden käytön opettelulle silloin, kun uuden välineen perustellusti katsotaan vähentävän työn rasitusta tai muulla tavoin helpottavan työn tekoa.

Toinen hyöty haastateltavien mukaan on se, että uutta työntekijää voidaan opastaa ohjeen avulla työprosessin suorittamisessa ja - viitaten ohjeiden turvallisuuskeskeisyyteen - se antaa luonnollisen lähtökohdan turvallisuudesta puhumiseen. Koska intervention ajankohtana uusia työntekijöitä rekrytoitiin vähän, perehdyttämisestä ohjeen avulla on vain vähän kokemusta. Vähät kokemukset olivat kuitenkin myönteisiä: ohjeita oli käytetty ainakin tilapäistyöntekijöiden opastamiseen. Etuna aikaisempaan opastamiseen nähden ohjeen koettiin helpottavan työtehtäviä koskevan yleiskuvan luomista ennen varsinaiseen käytännön työhön ryhtymistä.

Kolmantena hyötynä työntekijät kokevat sen, että turvallisuus on työn kuvauksen kiinteä osa. Aikaisemmissa mallituksissa turvallisuusnäkökohdat "... on ollu erillisinä, niitä ei oo työn yhteyteen ympätty.” (YH1107).

Kokeneet työntekijät kokivat niin ikään ohjeet hyödylliseksi omassa työssään. Yksi mainittu hyöty oli se, että ohjeet auttoivat palauttamaan mieleen sellaisia työtehtäviä, joiden hoitaminen ei kuulu jokapäiväisiin ammatillisiin tehtäviin. Erityisen merkittävää tämä on osastosiirtojen yhteydessä, jolloin työtehtävät, työympäristö ja työn vaatimukset vaihtelevat suuresti.

Haastateltavien mukaan ohjeet myös paransivat työprosessien ohjeistusta ja vähensivät tehtävän suorittamiseen liittyvää epävarmuutta. Tämän katsottiin vähentävän "kantapään kautta” oppimisen tarvetta ja siten vähentävän työn riskialttiutta.

TEKO:n onnistumista turvallisuusinterventiona arvioitiin kolmen kriteerin avulla. Ensiksikin sen perusteella, oliko telakan työntekijöiden turvallisuustietoisuus parantunut. Toiseksi, olivatko syyt käyttää riskialttiita työtapoja vähentyneet. Kolmanneksi, oliko turvallisuustilanne telakalla parantunut.

\section{TURVALLISUUSTIETOISUUS LISÄÄNTYI}

Turvallisuustietoisuutta on usein pyritty lisäämään valistuksen keinoin: pyrkimällä tekemään työntekijät tietoisiksi työn ja erityisesti erilaisiin työtapoihin liittyvistä riskeistä. Taustaoletuksena on, että työntekijä rationaalisena toimijana luopuu riskialttiiksi tietämistään työtavoista. Turvallisuustietoisuus itsessään lieneekin välttämätön ehto työturvallisuuden parantumiselle; työn vaaroista tietämätön työntekijä on luonnollisesti altis onnettomuuksille telakan kaltaisissa oloissa.

Työntekijöiden haastatteluiden pohjalta voidaan tehdä johtopäätös, jonka mukaan interventio on vaikuttanut turvallisten ja turvattomien työtapojen parempaan tiedostamiseen koskien mm. suojavälineiden käyttöä, välineiden ylikuormittamista ja oman ruumiin rasitusta.

Suojavälineisiin kiinnitettiin haastatteluiden mukaan aikaisempaa enemmän huomiota. Erityisen myönteisenä koettiin se, että myös telakan iäkkäimmät työntekijät, jotka perinteisesti ovat olleet tottumattomia tai haluttomia käyttämään 
suojavälineitä, olivat lisänneet niiden käyttöä. Työpaikkaohjaajien koulutus oli ilmeisesti myös lisännyt koulutettujen itseluottamusta puuttua työsuojelurikkomuksiin. Eräs haastateltava kertoi tapauksesta, jossa työpaikkaohjaaja oli kieltäytynyt yhteistyöstä työtoverinsa kanssa, mikäli tämä ei käyttäisi turvavaljaita korkealla työskentelyssä: "Kyl se vaan se turvavyö löyty." (YH0903)

Haastateltavat kokivat myös oman ruumiin rasituksen - esimerkiksi vaikeissa asennoissa työskentelemisen - vähentyneen ainakin omassa toiminnassaan. Erityisesti työkohteissa tapahtunut ergonomiakoulutus koettiin hyvänä ja haastateltavat kertoivat pyrkivänsä kiinnittämään aikaisempaa useammin löytämään mahdollisimman vähän kuormittavia työasentoja.

\section{INVESTOINNIT VÄHENSIVÄT RISKIKÄYTTÄYTYMISTÄ}

Pelkkä turvallisuustietoisuuden parantaminen ei ole riittävä ehto työturvallisuuden parantumiselle, koska työtehtäviin sisältyy lukuisia riskikäyttäytymiseen kannustavia elementtejä. (Rasmussen 1997.) Näitä elementtejä ovat telakalla mm. kiire, tilanahtaus, henkilösuojainten epämukavuus ja turvallisuutta lisäävien välineiden hankala saatavuus. (Rinne \& Hallikainen 2004, 207-208.) Siksi onkin välttämätöntä arvioida sitä, ovatko syyt riskikäyttäytymiseen vähentyneet.

Intervention aikana telakalla tehtiin lukuisia materiaalisia parannuksia. Esimerkiksi yhteen suureen halliin tehdyt mittavat investoinnit ja parannukset koettiin hyvin arvokkaiksi. "Hirvittävä rahallinen hyöty" olikin yksi konkreettinen projektin tuoma etu, koska yhtäältä projektin avulla päästiin vaikuttamaan patoutuneiden materiaalisten tarpeiden tyydyttämiseen, toisaalta projekti toimi perusteluna uusille investoinneille kuten silmäsuojainten, viiltohansikkaiden ja nostoapuvälineiden hankkimiselle.

Toteutetut materiaaliset uudistukset vähensivät kannusteita turvallisuusnormien rikkomiselle; kun välineiden saatavuutta parannettiin, kiusaus sivuttaa esimerkiksi turva-apuvälineiden (tikkaiden kiinnittimet, hallinostureiden tarraimet jne.) käyttö ollut ei erityisen suuri. Materiaalisten parannusten lisäksi monet haastateltavat mainitsevat oman työn hallinnan ja vaikutusmahdollisuuksien lisääntymisen projektin aikana. Keskeistä oli se, että työntekijät pääsivät itse toteutta- maan tarpeellisiksi koettuja uudistuksia vapaaehtoispohjalta. Tämä lisäsi myös ryhmähenkeä ja motivaatiota kehittämistoimintaa kohtaan: "Ja ei siin tarvinnu mittää mahtikäskyy. ... Et siit tuli semmone, et me oli itte pähkäilty, itte sanottu." (YH0904)

\section{TYÖTURVALLISUUSTILANNE PARANI AJANJAKSONA}

Oppimisen ja työturvallisuuden kannalta laivat ovat eräänlaisia "luonnollisia oppimisympäristöjä”, joissa oppimisesta maksetaan kovaa hintaa inhimillisenä kärsimyksenä ja tuotannollisina menetyksinä. Oppimista selvästikin tapahtuu: Tapaturmataajuus (eli onnettomuuksia miljoonaa työtuntia kohti) nimittäin pienenee aina saman laivatyypin osalta - eli silloin, kun olosuhteet pysyvät kohtuullisen samanlaisina. (Rinne \& Hallikainen 2004, 272-274.)

TEKO:n vaikutuksia arvioidessa on kuitenkin keskeistä, että turvallisuustilanne telakalla parani interventioajankohtana huomattavasti - voidaan siis olettaa, että TEKO-projektilla on ollut turvallisuusoppimista vauhdittava vaikutus. Turvallisuustilanteen kehitys kuvattuna interventioajanjakson (vuodet 2000-2003) ja lähtötason (vuosien 1996-1999 keskiarvo) vertailuna osoittaa, että interventioajanjaksolla tapaturmataajuus pieneni merkittävästi kahdella suurimmalla tuotanto-osastolla. (Kuvio 1.) Vuoteen 2003 mennessä runko-osastolla, joka on n. 1000 työntekijällään telakan suurin osasto, tapaturmataajuus oli ainoastaan 20 prosenttia lähtötasosta. Varusteluosastolla - noin 700 työntekijällään toisiksi suurin osasto - vastaava osuus oli 35 prosenttia. Yllättävää oli, että runko-osastolla tapaturmataajuus oli ensimmäistä kertaa tilastoidun telakan historiassa pienempi kuin varusteluosastolla.

Myönteinen kehitys heijastui myös lähestapaturmien määrään ja laivapaloihin. Lähestapaturmien määrä nousi vuonna 2001 mennessä huippuunsa (62 ilmoitettua vaaratilannetta). Tällöinhän tapaturmataajuudessa ei ollut tapahtunut mainittavaa muutosta parempaan tai huonompaan, mutta on olettavaa, että vaaratilanteiden raportointiherkkyys oli kasvanut. Huippuvuoden jälkeen lähestapaturmien määrä alkoi laskea ja vuonna 2003 ilmoitettiin ainoastaan 21 lähestapaturmaa koko telakalla. Samoin laivapalojen määrä väheni neljännekseen vuosina 2000-2003. 


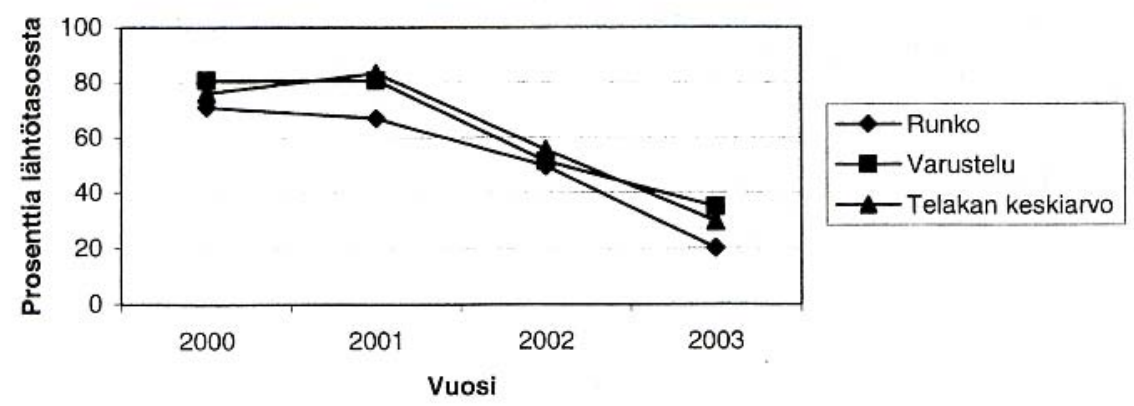

\section{KUVIO 1. TAPATURMATAAJUUDEN KEHITYS INTERVENTIOAJANKOHTANA} (KMY Turun uusi telakka)

\section{KARIKOT TEKO:N VÄYLÄLLÄ}

TEKO-projektia voidaan pitää kaiken kaikkiaan varsin hyödyllisenä ja toimivana tapana saada aikaan työturvallisuudessa muutos parempaan. Sekä haastattelu- että kyselyaineisto antaa kuitenkin viitteitä siitä, että projekti saattaa myöhemmin törmätä muutamiin tekijöihin, joihin ei sen vapaaehtoisuuteen ja epäbyrokraattisuuteen perustuvan luonteen vuoksi ole kyetty riittävästi kiinnittämään huomiota. Näitä tekijöitä ovat tietämättömyys projektin tarkoituksesta, jatkuvuuteen kohdistuva epäily, kuilu työnjohtajien ja työntekijöiden välillä sekä työpaikkaohjaajien roolin epäselvyys. Tähän "karikkoon törmääminen” voi pysäyttää myönteisen kehityksen kokonaan tai hidastaa työturvallisuuden parantumista telakalla.

\section{TIETÄMÄTTÖMYYS}

Yleisesti ottaen tiedotus TEKO-interventiosta oli toiminut hyvin silloin, kun sen kohteena olivat olleet työpaikkaohjaajat. Kysely 3:n mukaan 75 prosenttia kaikista työpaikkaohjaajista koki saaneensa riittävästi tietoa projektista. Ongelmana näyttää olevan ennen kaikkea rivityöntekijöiden informointi: vain 42 prosenttia heistä ilmoitti tietomääränsä olevan riittävä. On luultavaa, että myös työpaikkaohjaajat ovat työssään huomanneet tiedotuksen riittämättömyyden. Peräti 95 prosenttia työpaikkaohjaajista oli kyselyn mukaan sitä mieltä, että tiedotusta olisi lisättävä. Työntekijöistä 68 prosenttia oli tätä mieltä.

Yleinen epätietoisuus interventiosta ilmenee kyselyssä myös siten, että monet vastaajat olivat joko jättäneet vastaamatta väitteisiin, ympyröineet kaikki vaihtoehdot tai piirtäneet isompia ja pienempiä kysymysmerkkejä useiden kysymys- ten kohdalle. Monet eivät myöskään olleet tienneet tiiminsä työtapaohjeen aihetta, olivat vastanneet hyvin epätäsmällisesti (kuten "laadun ja turvallisuuden parantaminen") tai luulleet TEKO-projektin olevan sama asia kuin työtapaohjeen tekeminen (joissain tiimeissä näin on saattanut tietenkin ollakin). Avoimissa kommenteissa työntekijät kritisoivat TEKO-interventiota mm. hajanaisesta tiedotuksesta ja koko tiimin kattavien tiedotustilaisuuksien puutteesta.

Ilmeisesti tiedonpuute oli syynä siihen, että jotkut työpaikkaohjaajat kokivat intervention ainakin sen alkuvaiheessa - itselleen ulkokohtaiseksi. Tämä tuli esille mm. haastatteluissa, joissa pohdittiin projektin luonteelle kenties tärkeintä perustaa eli työntekijälähtöisyyttä. Koska ohjaajat eivät varsinkaan ensimmäisissä koulutusjaksoissa päässeet vaikuttamaan koulutuksen teemoihin, rakenteeseen tai toteutukseen, se koettiin joidenkin osallistujien keskuudessa muistutuksena tavanomaisen linjaorganisaation käskytysjärjestelmän olemassaolosta.

"No vähän vaikuttaa ettei oo ainakaan meijän kohdal ollu nii [työntekijälähtöinen]. Ylhäältä käsin meille on ainakin annettu, et meijän pitäis tehdä tämä meijän homma. Mut emmä sit tiedä. ... Kyl täs talos tuppaa olemaan semmonen." (YH0802)

\section{EPÄILY}

Työntekijöiden keskuudessa epäiltiin, että TEKOinterventio on jäämässä vain ohimeneväksi ilmiöksi. Kyselyssä 3 työntekijöiltä kysyttiin mielipidettä joissain haastatteluissa esiin nousseeseen käsitykseen, että projekti olisi "hyytymässä”. Yleinen mielipide vastanneiden keskuudessa oli kielteinen hyytymisoletukselle: vain 40 prosenttia 
työpaikkaohjaajista ja 48 prosenttia työntekijöistä sen sijaan sanoi käsityksenään, että projekti on hyytymässä. Kuitenkin sekä aloittamisen ajankohdalla että asemalla oli merkitystä käsityksiin projektiin hiipumisesta: mitä kauemmin vastaaja oli ollut TEKO-projektissa osallisena, sitä pessimistisemmin hän suhtautui projektin jatkoon. Toukokuussa 2001 aloittaneet pääsääntöisesti uskoivat hyytymiseen, kun taas marraskuussa aloittaneet olivat useimmin väitettä vastaan. Työpaikkaohjaajien käsitys oli kaikissa aloitusryhmissä rivityöntekijöitä optimistisempi.

Epäilystä huolimatta TEKO-projekti sai laajan kannatuksen sekä työpaikkaohjaajien että rivityöntekijöiden keskuudessa. Lähes kaikki vastaajat (80-100 \% aloitusryhmän ja aseman mukaan) olivat sitä mieltä, että projektia kannattaisi laajentaa.

Jos projektia kaiken kaikkiaan kannatetaan, mistä johtui "TEKO-pioneerien” keskuudessa yleinen käsitys sen hyytymisestä? Varovainen kyselyn vapaamuotoisiin kommentteihin ja haastatteluihin pohjautuva oletus on, että kysymys olisi ristiriidasta odotusten ja saavutusten välillä. Pioneerit olivat kyselyajankohtana ehtineet nähdä TEKO:n aktuaaliset saavutukset, kuten venyttelypaikat, jotka saattoivat tuolloin näyttää triviaaleilta varsinkin, jos niitä verrattiin työntekijöiden turvallisuuden ja terveyden merkittävään kohentumiseen tai oman päätösvallan lisääntymiseen.

Haastateltavat nostivat lisäksi esille joitakin aikaisempia interventioita, joilla työskentelyolosuhteita on pyritty muuttamaan, mutta joiden anti on koettu joko väliaikaisena tai triviaalina. Lisäksi he pelkäsivät, että ns. "muut projektit” - mitä ne ikinä lienevätkin - saattavat haudata alleen TEKO:n avulla tuodut uudistukset alleen. Käytännössä tämä viittaisi siihen, että työturvallisuusasiat siirtyisivät telakan prioriteeteissa toissijaisiksi tuotantotekijöihin nähden.

\section{KUILU TYÖNJOHTAJIEN JA TYÖNTEKIJÖIDEN VÄLILLÄ}

Työnjohtajilla on kiire huolehtia omista työtehtävistään, jolloin heidän huomionsa on kiinnittynyt lähinnä normaalien tuotantotehtävien kontrollointiin. Tämä tapahtuu usein stressaavissa olosuhteissa, kun pyritään optimoimaan työskentelyprosessi mm. ajansäästön ja kustannustehokkuuden kriteerien avulla. (Rasmussen 1997, 194.)
Tämä aiheuttaa telakalla kitkaa työntekijöiden ja työnjohtajien sekä insinöörikunnan välillä. Kitka heijastuu työntekijöiden käsityksissä, joiden mukaan työnjohtajat eivät ole riittävän sitoutuneita TEKO-projektin tavoitteisiin. Telakalla, kuten muillakin työympäristön kehittämiseen tähtäävillä työpaikoilla, tulisi kiinnittää asiaan erityistä huomiota.

Haastateltujen mukaan työnjohtajien sitoutumattomuus TEKO-projektiin ilmeni monilla tavoin. Esimerkiksi jotkut työntekijät uskoivat työnjohtajien pyrkivän ”aktiivisesti unohtamaan” projektin pelätessään lisääntyvää työmäärää tai oman asemansa menettämistä. Monet työntekijät kuitenkin kokivat, että työnjohtajien kannustus olisi erittäin tärkeää TEKO-projektin tavoitteiden saavuttamisen kannalta. Tätä kannustusta työntekijät kuitenkin pitivät riittämättömänä. Kannustuksen puutteen lisäksi ongelmalliseksi koettiin projektin aikana toteutetut osastosiirrot, jotka hajottivat projektiin perehtyneet työryhmät.

\section{TYÖPAIKKAOHJAAJIEN ROOLI JÄI EPÄSELVÄKSI}

Työpaikkaohjaajien rooli tuntui koulutuksen jälkeen olevan kadoksissa. Osittain tämän johtui siitä, että ohjaajat eivät toistaiseksi olleet saaneet uusia työntekijöitä ohjattavakseen.

Ajatus siitä, että ohjaajat olisivat sekä kokeneiden että kokemattomien työntekijöiden opastajia, koettiin ongelmallisena. Erityisiä ongelmia ajatuksessa ovat käsitykset auktoriteetista ja opastamisen vaikutuksista, jotka osin ovat yhteen kietoutuneita: ilman auktoriteettia on hankala saada työtovereita muuttamaan työtapojaan. Roolinmäärittelyn hankaluutta kuvastaakin se että ohjaaminen ymmärretään työnjohtoon liittyvänä valtakysymyksenä. Tästä perspektiivistä ohjaajan rooli rinnastuu työnjohtajan toimenkuvaan. Paitsi että tähän rooliin ohjaajat eivät suhtaudu erityisen myönteisesti, sitä ei myöskään pidetä realistisena. Eräs haastateltava kuvasi ongelmaa seuraavasti: "Kun mä yritin sitä viimeisessä infotilaisuudessa kysyä ... meijän esimieheltä, et mitä me nyt sit ollaan. Et onko meillä - emmä nyt tarkota jotai valtaa - mut et me voitais niinku sanoa jolleki jotai? Emmä kyllä näillä palkoilla ruppee ketää tuolla määräilemää tai jottai vastaavaa." (YH0402) 


\section{LOPUKSI}

Robert Karasekin ja Töres Theorellin (1990) kehittämän Vaativuus-hallintamallin mukaan monet työturvallisuus- ja terveysongelmat aiheutuvat työn vaativuuden ja hallinnan eli päätöksentekovapauden yhteisvaikutuksesta. Työntekijöiden turvallisuuden ja terveyden kannalta ongelmallisimmat työt ovat ns. korkean rasituksen työt (joissa korkea vaatimustaso yhdistyy huonoihin hallinnan mahdollisuuksiin) sekä passiiviset työt (joissa työn matala hallinta yhdistyy huonoihin vaikutusmahdollisuuksiin). Työyhteisön tarjoama sosiaalinen tuki vähentää terveysriskejä, muttei poista niitä.

Vaativuus-hallintamallin näkökulmasta TEKO vaikuttaa varsin lupaavalta vaihtoehdolta perinteisten valistuskampanjoiden ja turvallisuuskilpailujen, samoin kuin kaupallisten turvallisuusjärjestelmien (DuPont, Toyota ym.) täydentäjäksi. Erityisen tärkeää on se, että TEKO -projektin eri osa-alueilla voidaan nähdä olevan pääasiassa työtä monipuolistava ja työn hallintaa lisäävä vaikutus. Esimerkiksi työtapaohjeiden tekeminen laajensi työtä opetus- ja suunnittelutyön suuntaan erilaisten pienkehityshankkeiden lisätessä työn vaativuutta. Turvallisuuden ja siten myös työn hallinta parani, kun työntekijät kykenivät tekemään koulutusohjelman mukaisia päätöksiä oman työympäristönsä kehittämiseksi. Samalla työpaikkaohjaajat saattoivat parhaimmillaan toimia tärkeänä sosiaalisen tuen lähteenä telakalla.

Kysymyksen herättäminen siitä, kuinka aikuisja täydennyskoulutus vaikuttaa työn hallintaan, onkin yksi tärkeimmistä TEKO-intervention saavutuksista. TEKO:n onnistuminen on kytköksissä pitkälti siihen, että rivityöntekijät, ohjaajat, työnjohtajat ja insinöörit kykevät irrottautumaan rutiinitöistään itse tarpeellisiksi kokemiensa kehityshankkeiden ajaksi. Haasteen voi esittää myös muille aloille kuin telakkateollisuuteen eikä aihettakaan tarvitse rajoittaa työturvallisuuteen. Mikäli koulutetut eivät kykene soveltamaan oppimaansa, häviäjäosapuolia on ainakin kolme: (1) työnantaja, joka maksaa turhasta koulutuksesta, (2) koulutettavat, jotka käyttävät energiaansa käytännössä tarpeettomien taitojen oppimiseen ja (3) aikuiskasvattajat, jotka koulutusohjelmia laatiessaan ja soveltaessaan tekevät Sisyfoksen työtä.

\section{VIITTEET}

1. Artikkeli perustuu Rinteen ja Hallikaisen (2004) seurantatutkimukseen, jonka rahoittivat Työsuojelurahasto ja Työministeriö. Kiitän Petri Haltiaa ja Sirkku Rautakilpeä hyödyllisistä kommenteista.

2. Tätä direktiiviä ovat lähemmin tarkastelleet mm. Walters 1995 ja Walters \& Jensen 2000.

\section{LÄHTEET}

Cox, S. \& Cox, T. (1996) Safety, Systems and People. Butterworth-Heinemann, Oxford.

Hallikainen, P. (2004) Promoting Safety in Industry: Role of Workplace-tutors. Paper presented at European Conference on Educational Research, University of Crete, 24-25 September 2004.

Karasek, R. \& Theorell, T. (1990) Healthy work - stress, productivity and the reconstruction of working life. Basic Books, New York.

Koskensyrjä, M. \& Vainio, J. (1999) Turvallisuuden mittaaminen ja menetelmät. Tampereen teknillinen korkeakoulu (turvallisuustekniikka), raportti 81.

Rasmussen, J. (1997) Risk management in a dynamic society: A modelling problem. Safety Science 27 (2/3), 183-213.

Rinne, R. \& Hallikainen, P. (2004) Turvalliseen laivantekoon työssä oppien: Seurantatutkimus KMY Turun uuden telakan työssäoppimisprojektista (TEKO). Teoksessa: Suomalainen laivanteko 2000-luvun vaihteessa: Työstä, turvallisuudesta ja oppimisesta suomalaisessa telakkateollisuudessa. Rinne, R., Haltia, P., Hallikainen, H., Himberg, H. Turun yliopiston kasvatustieteiden julkaisuja: 202.

Ruuhilehto, K. \& Vilppola, K. Turvallisuuskulttuuri ja turvallisuuden edistäminen yrityksessä. TUKES-julkaisu 1/2000, Helsinki.

Walters, D. (1995) Employee representation and occupational health and safety: the significance of Europe. Journal of Loss Prevention in the Process Industries. 8 (6), 313-318.

Walters, D. \& Jensen, P. (2000) The Discourses and Purposes Behind the Development of EU Framework Directive 89/391. Teoksessa: Systematic Occupational Health and Safety Management. Perspectives on an International Development. Frick, K., Jensen, P., Quinlan, M. \& Wilthagen, T. (eds.) Elsevier Science Ltd, Netherlands. 